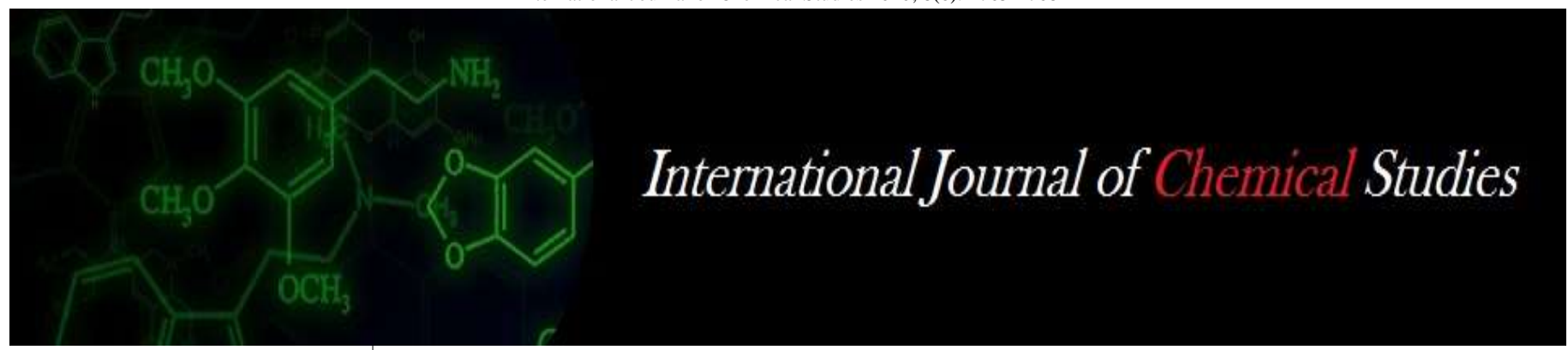

P-ISSN: 2349-8528

E-ISSN: 2321-4902

www.chemijournal.com

IJCS 2020; 8(6): 1765-1768

(C) 2020 IJCS

Received: 27-09-2020

Accepted: 22-11-2020

\section{Akshay Kuma}

Department of Agronomy,

School of Agriculture, Lovely

Professional University,

Phagwara, Punjab, India

Dr. Sandeep Menon

Department of Agronomy,

School of Agriculture, Lovely

Professional University,

Phagwara, Punjab, India

\section{A review on integrated nutrient management an approach to sustainability}

\author{
Akshay Kumar and Dr. Sandeep Menon
}

DOI: https://doi.org/10.22271/chemi.2020.v8.i6y.11023
Corresponding Author: Akshay Kumar

Department of Agronomy, School of Agriculture, Lovely Professional University, Phagwara, Punjab, India

\begin{abstract}
Organic manures are used traditionally to supply plant nutrients. The volume of organic fertilizers is high they are bulky in nature so, there are many problems in application of these fertilizes which forces farmers to use synthetic fertilizers. Using organic fertilizers helps to recycle the organic waste. The end product which is obtained from organic waste can provides nutrients in a efficient manner and also improves conditions of the soil. Because synthetic fertilizers which are currently in the use may not fulfil or maintain the quality of soil needs for sustainable agriculture. By applying all essential nutrients through synthetic fertilizers can degrades the quality and health of the soil which directly responsible for unsustainable yields. So, to improve the nutrient supply in integrated nutrient management system chemical fertilizers and organic manures should be combined together for best outputs. To maintain the soil fertility and proper soil health balanced application of organic and inorganic nutrient is required. Through integrated management sustainability in agricultural productivity should be achived. By using Integrated nutrient management on yield components of crops is very important for guarantee of food security. Integrated nutrient management or supply focus at maintening the fertility of soil and nutrient supply for plants to an optimum level in relation to sustain the desired crop productivity by optimizing the all sources of plant nutrients with the help of integrated nutrient management which can also includes other aspects like; maintainence or enhancement of soil productivity by using chemical fertilizers and organic fertilizers in a balanced manner. Different types of organic materials such as bio compost, FYM, green manures, vermicompost, crop residues, industrial wastes, composts, animal manures.
\end{abstract}

Keywords: Organic waste, synthetic fertilizers, INM, organic manures

\section{Introduction}

The organic manures are used to improve health of soil and supplying nutrients to plants since times. Different types and organic sources are utilized in agricultural practices but most of remaining materials are unutilized. Organic materials are bulky and available in city waste, farmyard manure, poultry manure and Industry wastes. If these materials are not recycled these may becomes a cause for air, water and land pollution. Large amounts of organic wastes are available in the forms of city waste, farm waste, poultry litter, sewage sludge and agro industrial wastes (Lal, 2005; Kolay, 2000) ${ }^{[9,10]}$. The different types of organic manures are used in the fields by farmers for sustainable yield of crop. But due to variation in composition, level of water they consist and bulky nature, application and transportation of organic manures is a big problem in this world where people are cocius for fuel. The application of these bulky manures are also increase labour requirements to a certain extent, which is also responsible for high input cost and that is not a economical option for a average or poor farmer. Composting is an very effective and eco- friendly approach for the disposal of organic waste (Millner et al., 1998) because it is cost effective and eco- friendly. It also helps in conservation of natural resources and also improves the cycling of non-renewable resources. Keeping present energy crises in view it is an very good option for conservation of energy because a large amount of energy utilized in fertilizer sector. This process converts organic waste into stable humus forms, which are stored and apply in agricultural practices without causing any harmful effects to environment (Gallardo-Larva \& Nogales, 1987) ${ }^{[8]}$. The organic compost and manures plays very important role in sustaining farming by providing efficient supply of nutrients (Korsaeth et al., 2002). The production of compost for agriculture has got attention due to sudden increase in prices of fertilizer and lowering in quality of soil. This is may be due to increment in costs of waste management and also awareness for wastes recycling in people. 
Compsting is a process which is a very good way to manage large volumes of organic wastes in a good manner (Stetiford, \& Lasaridi, 1999). Organic matter is available in different forms and different stages of organic matter decomposition at various stages is used in soil application at high quantity in tons/ha for improvement in productivity of crop (Terrance et al., 2004). The application of synthetic chemical fertilizers is very important for the proper nutrition of crop which helps in increasing productivity of crop. The yields of cereal crop like wheat are not increasing from last couple of years. The application of natural organic manures and organic materials composted along with synthetic chemical fertilizers can helps to increase in yield of crop further. The poor fertilizer management has a major reason for low productivity of crop yields, so for the achievement of optimum crop yield productivity nutrients have to manage through integrated nutrient management of organic and inorganic sources which are required. The management of fertilizer is a very important factor to increase the yield and growth of any crop (Ghaffari, et al., 2011) ${ }^{[2]}$. Integrated nutrient management (INM) is a system in which inorganic and organic nutrient sources are combined for the maintainence of soil health and to enhance crop yield. The application of appropriate and efficient supply of required nutrients through both inorganic and organic provides the solutions for the different problems like increment in prices of synthetic fertilizers, deterioration in quality of soil and productivity of the soil. Hence, combined application of these combinations helps in sustaining fertility of soil and productivity of soil.

\section{Concept of Integrated nutrient management (INM)}

Integrated nutrient management (INM) is a approach in which complete application of synthetic fertilizer and organic resources is a better, effective integrated method (Janssen, 1993). It also helps to improve the health of the soil by improving physio-chemical properties, reduces the degradation of soil and boost productivity of farm (Janssen, 1993, Esilaba et al., 2004). INM is not just only help to increase growth of crop but also it preserves the resources of soil. It mainly stresses on the application of farm wastes, farm yard manure (FYM), organic fertilizers, soil amendments, green manures, crop residues, crop rotations, cover crops, intercropping, conservation tillage, drainage and irrigation for the preservation of stable reserved water and for enhancement of the nutrients of plant (Janssen, 1993). INM requires the proper amount of nutrient and timing of nutrient application to be in relation with the nutrient uptake capacity of crop, which directly impliments to maximize the yield and also helps to improves the nutrient-use efficiency of crop (Cassman et al., 2002).

\section{Components of Integrated nutrient management (INM)}

Generaly INM is a effective use of both organic and synthetic fertilizers integrated together. Where synthetic or chemical fertilizers cosists components which have all essential macro nutrients like, NPK in the forms like Urea, SSP, MOP, DAP, Urea etc for the enhancement of the growth factors in a eminent manner. But excessive or overuse of these chemicals can detiorates the fertility of soil so Integrated Nutrient Management comes into attention. There are different components of INM which includes improvement in health of soil, helps to restores the crops like leguminous crops, green leaf manures, etc; recycling of residues which are remains from the crop; application of organic manures like biogasslury, FYM, vermicompost, poultry manure, biological composts, oil cakes, by utilization of biological agents; proper and application of nutrients through a proper manner in an integrated way fertilizers as per the requirements of crop to improve the yields of crop.

\section{Effect of $\mathbf{N}$ - fertilizers in INM}

$\mathrm{N}$ fertilizer have leaching problems of nitrates into ground water due to improper use of $\mathrm{N}$ fertilizer which can results more discharge losses to environment. Integrated nutrient management helps to reduce the nitrogen losses, reduce injurious environmental effects and also results in crop growth and high productivity in crops (Gruhn et al., 2000). The leaching of nitrogen is influenced by various aspects, like pattern of nitrogen application, soil properties, crop characteristics, administration practices and climatic situations. So, INM helps to enhance the Nitrogen-use efficiency which minimize the volatilisation losses of $-\mathrm{NH} 3$ and reduce leaching of nitrate (Sharma and Bali, 2018) ${ }^{[33]}$.

\section{Effect of Organic fertilizer}

The organic fertilizer which supply nutrients to plants include budding of legumes in the farming system, organic manures, green manures, crop leftover, (FYM, compost, vermicompost, biogas slurry, phosphorus-compost, bio-compost, oil cakes, green manure, biofertilizers etc. According to information which is available till now shows that organic manures as compare to fertilizers are more preffered to sustain the high yields of crops over longer periods, in comparision to single use of synthetic fertilizers. In various researches it is found in results that The results of various researches the possibility for stand in for more than $25 \%$ of RDF with organic sources in the intensive cropping systems. When legumes and green manures applied into harvesting system under perfect conditions it has the capability to meet more than $50 \%$ requirement of nitrogen in the rice crop. The soil is a basic need/requirement for the production of crop because it provides water, nutrients and support to the plants. An stable supply of organic and inorganic sources of nutrient is available in soils, but these nutrients are often completed with the help of external application of fertilizer for better performance of plant (Smaling, 1993). Natural or organic fertilizers are the final product of animal waste, plant residues, organic manures and even other wastes which are recyclable and bio-fertilizers, like fishery wastes, municipal wastes, etc. Application of organic fertilizers has number of advantages like improvement in soil structure physically and capacity of soil to hold water are enhanced drastically, organic fertilizers helps to increases the soil capacity to buffer changes in the $\mathrm{pH}$, also increases the cation exchange capacity, fixation of diminish phosphate, and it is a reservoir for all types of nutrients essential for crop plants. Organic matter results to more soil microorganisms and soil fauna, which are the important to operate the decomposition of organic matter and which results in releasing of mineral nutrients in the ecosystem of soil (Janssen, 1993). By Integrating all of fertilizers which contain NPK with organic manure, like vermicompost, which helps in building the fertility of the soil according to soil nutrient availability and supply of $\mathrm{C}$ and $\mathrm{N}$ in the soil formed by microorganisms (Anwar, 2005). The goat manure and poultry manure has ability to quick supply of nutrients than FYM and they help in conversion of non-available form of nitrogen to available form of nitrogen (Thavaprakash, 2005) ${ }^{[35]}$. 


\section{Green manuring}

Organic farming is totally dependent on soil health and recycling of nutrients by using natural processes in the soil. Green manures performs a vital role in fertilization, in concert with the addition of animal manures if those are used. It is quite promising application of green manures has helps to enhance crop yield and fertilizer saving (Dixit, 2007) ${ }^{[11]}$. Green manuring application is done with plowing under or soil incorporation of any green manuring crops ehen they are green or soon after flowering. Green manures are leguminous crops or forage crops which are grown for their leafy material used in the soil conservation losses. Results of some studies shows that 18 grain legume species are very important for green manuring in different farming situations of rice in Asia.

\section{Effect of bio-fertilizers}

Bio-fertilizers are the fertilizers which are formed from organic or natural substances mainly they are of nitrogen fixing type and $\mathrm{p}$ - solubilising type; these both type of biofertilizers are generally acts on the rhizosphere of plant and also improve growth of plant by providing them essential nutrients.

\section{Different types of bio fertilizer and their effect on plant}

- Nitrogen fixing type: Rhizobium inoculation used as nitrogen fixing of legume crop is an important practices which are adopted in the different parts of different countries. It shows its major effect of growth on formation of nodule, leaf growth, yield of grains and content of protein in peas (Mckenzie et al., 2001) azospirrilum and azotobacter also helps in enhancement of the nitrogen effect in plant.

- Phosphate solubilising type: Phosphate solubilising microorganism (PSM) helps mainly to enhance the effect of phosphorus in the plant and also in the soil. Penicillium bilaiae inoculation could helps to enhance percentange of available phosphorus in the soil and improves the quality of dry matter, grain yield, and uptake of phosphorus in wheat (Kucey, 1987). It is also used for consistent improvement of total organic crops.

\section{Strategy for INM improvement}

INM is integration of synthetic and natural fertilizers. So, this system of fertilizer application can implemented by farmers because the it has many environmental benefits and also helps to sustain the agricultural methods/techniquies. By studying and go through different reports of research, by concluding recent methods which can be undertaken by the farmers and further can be boosted by some modifications and adjustments into them the implementation of site-specific INM practices. INM is an futuristic approach to improve environmental conditions, mechanization due to serious labour shortage, conservation tillage and rain water-harvesting methods, recycling of organic nutrient flow, new technological innovations, are some of the issues which could be given importance to promote INM.

\section{Conclusion}

Integrated nutrient management system is growing faster in the agricultural farming system throughout the whole world due to its efficiency and effectiveness in both quality as well as in productive factor. In this system we can use both organic and synthetic fertilizer has a judicial and plays effective role in the enhancement of the yield of crops and also helps to increase the economic condition of the farmers different countries of world. Some different agencies of government and department of agriculture should have to look forward in improving the condition of farmers to adopt integrated method of farming because single use of synthetic fertilizers detoriates the quality and productivity of the soil and also have adverse effect on the environment. Organic farming cannot fulfil the food requirement of the world so integrated farming is most effective to tackle this problem.

\section{References}

1. Ahmad R, Naveed M, Aslam M, Zahir ZA, Arshad M. Economizing the use ofnitrogen fertilizer in wheat production through enriched compost. Renew. Agric. \& Food System 2008;23(3):(In press).

2. Ghaffari A, Ali A, Tahir M, Waseem M, Ayub M. Influence of Integrated Nutrients on Growth, Yield and Quality of Maize (Zea mays L.). American Journal of Plant Science 2011, 63-69.

3. Iqbal A, Iqbal MA, Raza A, Akbar N, Abbas RN, Khan HZ. Integrated nitrogen management studies in forage maize. American-Eurasian Journal Agricultural \& Environment Science 2014;14(8):744-747.

4. Abay Ayalew, Tesfaye Dejene. Combined Application of Organic and Inorganic Fertilizers to Increase Yield of Barley and Improve Soil Properties at Fereze, In Southern Ethiopia Innovative 2012.

5. Systems Design and Engineering www.iiste.org ISSN 2222-1727 (Paper) ISSN 2222-2871 (Online) 3(1):201.

6. Chang C, Janzen HH. Long-term fate of nitrogen from annual feedlot manure application. J Environ. Qual 1996;25:785-790.

7. Dixit KG, Gupta BR. Effect of Farmyard manure, chemical and Biofertilizers on yield and quality of rice (Oryza sativa L.) and soil properties. J Indian Soc. Soil Sci 2000;48:773-780.

8. Gallardo-Larva F, Nogales R. Effect of application of town refuse compost on the soil plant system - A review. Biol. Wastes 1987;19:35-62.

9. Lal R. World crop residues production and implications of its use as a bio-fuel. Environ. Intl 2005;31:575-584.

10. Kolay AK. Basic Concepts of Soil Science. 2nd Ed. New-Age International Publisher, New Delhi 2000, 256.

11. Dixit RS. Cropping system research. Kalyani publishers. Ludhiana (India) 2007, 194

12. Buresh RJ, Datta SK. Nitrogen dynamics and management in rice legume cropping systems. Adv. Agron 1991;45:1-52.

13. Bhushan A, Khare N. Effect of Organic Manure and Spacing on the Growth and Yield Performance of Baby Corn under Poplar Based Agroforestry System. Int. J Curr. Microbiol. App. Sci 2018;7(3):3015-3019.

14. Cho JY, Son JG, Song CH, Hwang SA, Lee YM, Jeong SY et al., Integrated nutrient management for environmental-friendly rice production in salt-affected rice paddy fields of Saemangeum reclaimed land of South Korea. Paddy and Water Environment 2008;6(3):263-273.

15. Dar EA, Harika AS, Tomar SK, Tyagi AK, Datta A. Effect of crop geometry and nitrogen levels on quality of baby corn (Zea mays L.) as fodder. Indian Journal of Animal Nutrition 2014;31(1):60-64.

16. Department of Agriculture \& Cooperation, Ministry of Agriculture, Government of India, Guidelines on The National Project on Management of Soil Health and Fertility 2008. 
17. Hemmat A, Aghilinategh N, Rezainejad Y, Sadeghi M. Long-term impacts of municipal solid waste compost, sewage sludge and farmyard manure application on organic carbon, bulk density and consistency limits of a calcareous soil in central Iran. Soil and Tillage Research 2010;108(1-2):43-50.

18. Jat LK, Singh SK, Latare AM, Singh RS, Patel CB. Effect of dates of sowing and fertilizer on growth and yield of wheat (Triticum aestivum) in an Inceptisol of Varanasi. Indian Journal of Agronomy 2013;58(4):611614.

19. Kannan RL, Dhivya M, Abinaya D, Krishna RL, Krishnakumar S. Effect of integrated nutrient management on soil fertility and productivity in maize. Bulletin of Environment, Pharmacology and Life Sciences 2013;2(8):61-67.

20. Kumar M, Baishaya LK, Ghosh DC, Gupta VK, Dubey SK, Das A et al. Productivity and soil health of potato (Solanum tuberosum L.) field as influenced by organic manures, inorganic fertilizers and biofertilizers under high altitudes of eastern Himalayas. Journal of Agricultural Science 2012;4(5):223.

21. Lakshmi CH, Rao PC, Sreelatha T, Padmaja G, Madhavi M, Rao PV et al., Residual effects of INM on humus fractions, micronutrient content and their upake by rabi greengram under rice-pulse cropping system. Research on Crops 2014;15(1):96-104.

22. Liang Q, Chen H, Gong Y, Yang H, Fan M, Kuzyakov Y. Effects of 15 years of manure and mineral fertilizers on enzyme activities in particle-size fractions in a North China Plain soil. European Journal of Soil Biology 2014;60:112-119.

23. Liang Y, Yang Y, Yang C, Shen Q, Zhou J, Yang L. Soil enzymatic activity and growth of rice and barley as influenced by organic manure in an anthropogenic soil. Geoderma 2003;115(1-2):149-160.

24. Liu CA, Li FR, Zhou LM, Zhang RH, Lin SL, Wang LJ et al., Effect of organic manure and fertilizer on soil water and crop yields in newly-built terraces with loess soils in a semi-arid environment. Agricultural Water Management 2013;117:123-132.

25. Lone AA, Allai BA, Nehvi FA. Growth, yield and economics of baby corn (Zea mays L.) as influenced by integrated nutrient management (INM) practices. African journal of agricultural research 2013;8(36):4537-4540.

26. Mahanta D, Bhattacharyya R, Gopinath KA, Tuti MD, Jeevanandan K, Chandrashekara Arunkumar $\mathrm{R}$ et al., Influence of farmyard manure application and mineral fertilization on yield sustainability, carbon sequestration potential and soil property of gardenpea-french bean cropping system in the Indian Himalayas. Scientia horticulturae 2013;164:414-427.

27. Mahapatra A, Barik AK, Mishra GC. Integrated Nutrient Management on Baby Corn (Zea mays L.). International Journal of Bio-resource and Stress Management 2018;9(1):44-48.

28. Mahapatra A, Mishra GC, Barik AK. Integrated nutrient management in baby corn and its residual effect on green gram under rainfed ecosystem of Odisha. International Journal of Agriculture, Environment and Biotechnology 2018;11(3):433-438.

29. Marimuthu S, Surendran U, Subbian P. Productivity, nutrient uptake and post-harvest soil fertility as influenced by cotton-based cropping system with integrated nutrient management practices in semi-arid tropics. Archives of Agronomy and Soil Science 2014;60(1):87-101.

30. Naidu DK, Radder BM, Patil PL, Hebsur NS, Alagundagi SC. Effect of integrated nutrient management on nutrient uptake and residual fertility of chilli ( $\mathrm{Cv}$. byadgi dabbi) in a vertisol. Karnataka Journal of Agricultural Sciences 2009;22(2):306-309.

31. Rahman MH, Islam MR, Jahiruddin M, Rafii MY, Hanafi MM, Malek MA. Integrated nutrient management in maize-legume-rice cropping pattern and its impact on soil fertility. J Food Agric. Environ 2013;11(2):648-652.

32. Ranjan JK, Ahmed N, Das B, Ranjan P, Mishra BK. Green Technology for production of baby corn (Zea mays L.) under North-West Himalayan conditions. International Journal of Chem Tech Research 2013;5(2):880-885.

33. Sharma LK, Bali SK. A review of methods to improve nitrogen use efficiency in agriculture. Sustainability 2018;10(1):51.

34. Thavaprakaash N, Velayudham K. Effect of crop geometry, intercropping systems and INM practices on cob yield and nutrient uptake of baby corn. Asian Journal of Agricultural Research 2007;1(1):10-16.

35. Thavaprakaash N, Velayudham K, Muthukumar VB. Effect of crop geometry, intercropping system and nutrient management on cob yield and nutrient uptake of baby corn (Zea mays L.). Madras Agric. J 2005;92(1012):646-652.

36. Thavaprakaash N, Velayudham K, Muthukumar VB. Effect of crop geometry, intercropping systems and integrated nutrient management practices on productivity of baby corn (Zea mays L.) based intercropping systems. Research Journal of Agricultural and Biological Sciences 2005;1(4):295-302.

37. Wailare AT. Effect of Integrated Nutrient Management on Baby Corn (Zea mays L.) A Review. International Journal of Science and Research (IJSR) 2014;3(6):22182222.

38. Xu MG, Li DC, Li JM, Qin DZ, Kazuyuki Y, Hosen Y. Effects of organic manure application with chemical fertilizers on nutrient absorption and yield of rice in Hunan of Southern China. Agricultural Sciences in China 2008;7(10):1245-1252. 